\title{
Machado e Eça ou \\ a mão e a luva: Tótem \\ e não Tabu
}

Maria Manuel Lisboa*

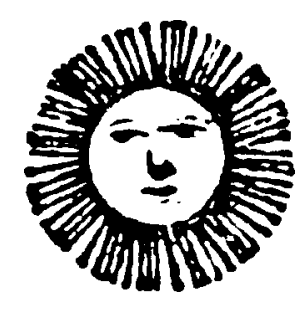

* Universidade de Cambridge. 
Ao regressar aqui à já tão cansada polémica de $\mathrm{M}$ achado com $\mathrm{E}$ ça ${ }^{1}$ por ocasião da resenha a'O Primo Basíli o publicada em $1878,{ }^{2}$ pretendo ensaiar uma nova abordagem que deite luz por um lado sobre certos aspectos do pensamento de M achado enquanto crítico literário, aspectos esses que transparecem da dialéctica entre a sua postura analítica e a história dos dois movimentos literários, o Romantismo e o Realismo, que a sua obra ensaística abrangeu; e por outro lado, sobre motivações porventura mais subterrâneas que insuflam a obra de ficção do escritor brasileiro.

O calor com que Machado, embora repetidamente cortejando o mérito de Eça, condenou O Primo Basílio, aponta ostensivamente para os defeitos de um movimento, o Naturalismo, cujas falhas ele declara atingirem o cerne da produção do romance queirosiano. Assim, quando M achado acusa E ça de ter criado em Luísa não uma pessoa moral mas "um títere," ${ }^{3}$ vítima "de uma queda que nenhuma razão moral explica, nenhuma paixão, sublime ou subalterna, nenhum amor, nenhum despeito, nenhuma perversão sequer" (905), sendo Luísa uma criatura que "resvala no lôdo, sem vontade, sem repulsa [e] sem consciência" (905), é supostamente o Naturalismo que ele condena, e apenas indirectamente $\mathrm{E}$ ça como o discípulo talentoso mas equivocado daquele movimento.

E mbora algumas das observações de M achado sejam justas, por exemplo, a crítica fundamental da importância que a estrutura do enredo outorga ao elemen-

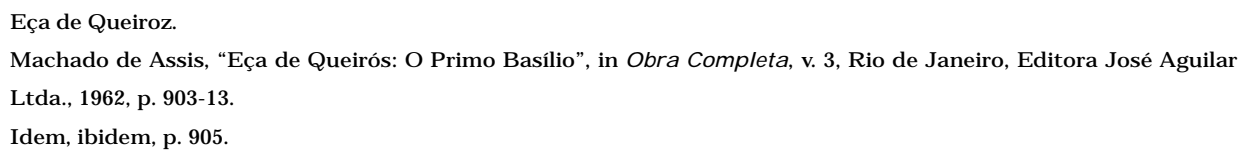


to meramente acessório à trama (se as cartas não tivessem sido sonegadas por J uliana, o romance acabaria quando B asílio parte para Paris e J orge regressa do Alentejo), o tom do texto aponta para um envolvimento mais directo e pessoal, dir-se-ia até, mais visceral, do que o puramente impessoal do crítico em polémica com a escola a que se opõe. No embate de machos entrechocando presas que se pressente por detrás da dignidade recenseadora de Machado, há algo de quase F reudiano, ou edipiano, se não de filho contra pai (visto terem sido os dois escritores quase exactamente contemporâneos, um nascido seis anos antes do outro, um morto oito anos antes do outro), pelo menos de herd eiro estético, e relutantemente herdeiro, de uma poética cuja influência ele tentou recusar mas à qual não conseguiu por fim fugir.

Visto que aqui me situo em paragens F reudianas, é talvez pertinente observar que tanto em Machado como em Eça, o tema do incesto aparece repetidamente como mola cativante da trama. E $m$ Eça, porém, o incesto é não só simbólico ( por exemplo no caso de A maro, padre e confessor, e de A mélia, sua filha espiritual e confessada, acerca de quem se diz além do mais que "ai, eram como irmãos"4), mas, e com maior frequência, concretamente consanguíneo ( Luísa e Basílio são primos, Carlos e M aria Eduarda são irmãos); ao passo que em M achado, uma maior hesitação perante o tabu obriga a que seja esse incesto timidamente aventado mas depois dissipado. Assim, Helena e Estácio provam-se não serem afinal de contas irmãos, I aiá G arcia e E stela, ambas amadas por J orge, são não mãe e filha mas enteada e madrasta, Capituzinha e Ezequiel, possivelmente meios-irmãos em resultado do adultério de Capitu e Escobar, não se casam como hipotetizado, e Flora morre antes de ser tentada a amar carnalmente os irmãos gémeos $\mathrm{Pedro}$ e $\mathrm{P}$ aulo). Onde $\mathrm{E}$ ça ousa, por conseguinte, $\mathrm{M}$ achado vacila, perante o tema antigo e moderno, grego e Freudiano do incesto.

M as é noutro aspecto também já psicanaliticamente desvendado, nomeadamente o da relação de percursor artístico que, como aqui pretendo propôr, Eça foi para Machado, e que é relação de pai para filho, que houve talvez da parte de Machado o ímpeto edipiano de castração ou assassinato desse pai amado e invejado. A atribuição a Eça do estatuto de percursor estético de Machado requer elaboração perante o facto já aludido da quase exacta contemporaneidade dos dois escritores. M as é verdade que, se bem que contemporâneos em termos puramente biográficos, na dimensão de uma evolução artística canónica, Eça, pai europeu, antecipou-se ao mestre brasileiro, sendo que dos três grandes romances daquele, dois deles, O Crime do Padre Amaro (datando de 1875) e O Primo Basílio (de 1878), foram publicados respectivamente três e seis anos antes do romance

4 E ça de Queirós, O Crime do Padre Amaro, Lisboa, Livros do Brasil, s.d., p. 479. 
que primeiro estabeleceu a estatura de Machado como romancista, as Memórias Póstumas de Brás Cubas. E o golpe de mestre de Eça, Os Maias, publicado em 1888, antecedeu de onze anos o reconhecido zénite do romance machadiano, Dom Casmurro, publicado em 1899.

Pai e filho, então, reproduzindo ademais, como indivíduos e como artistas, o conflicto entre metrópole e ex-colónia, e um pai e um filho, acima de tudo, em combate na encruzilhada edipiana do acto narrativo criador, que é o acto genesíaco por excelência de reclamação do dom da palavra quer para deuses ("no princípio já existia o Verbo, e o Verbo estava com Deus, e o Verbo era Deus" diz-nos São J oão no seu E vangelho ${ }^{5}$ ), quer para homens: “então o Senhor Deus, após ter formado da terra todos os animais dos campos e todas as aves dos céus, conduziu-os até junto do homem, a fim de verificar como ele os chamaria, para que todos os seres vivos fossem conhecidos pelos nomes que o homem Ihes desse." 6 Se é o dom do Verbo, ou da palavra, que aproxima os homens de Deus e Ihes dá a ilusão ou a possibilidade de imortalidade, a vantagem de possuír a primeira palavra merece o reconhecimento mais ordinariamente atribuído à última. É esta vantagem, a da posição de quem primeiro fala ou enuncia ou cria ou nomeia, que, de ângulos diferentes, determina as propostas para uma emergência de linhas geracionais de artistas, variamente avançadas por T.S. Eliot e Harold Bloom, nas quais aqui me basearei para fim de estabelecer um elo entre a primeira palavra queirosiana e a última - mas talvez não final - de M achado.

No seu livro, The Anxi ety of I nfluence (A Ansiedade da Influência), 7 B loom parafraseia a história literária como compreendendo sucessivas gerações de poetas subjugados por um complexo de É dipo que os mantém acorrentados a uma ansiedade derivada da sombra projectada pelo poeta que os precedeu, como o filho edipiano é dominado pelo pai. Segundo Bloom, cada poema pode ser lido como a tentativa de escapar a esta ansiedade de influência, através da remodelação sistemática de um poema prévio, sendo que o poeta enredado em rivalidade edipiana com o seu antepassado castrador, tenta enfraquecer a força deste, revendo e desmontando a sua obra. Cada poema, então, segundo Bloom, é uma tresleitura e trescritura de um poema anterior, e o poeta "forte" é aquele que tem a coragem de reconhecer que o seu Verbo não é o primeiro, e que torpedeia com êxito o poder de primazia do poeta antecessor. Cada poema vem por conseguinte a desempenhar esse acto de contestação de um poema prévio, e por conseguinte, segundo esta fórmula, o significado de um poema é afinal até certo ponto, e sempre, outro poema prévio. Neste cenário primevo de pais e filhos poetas afundados

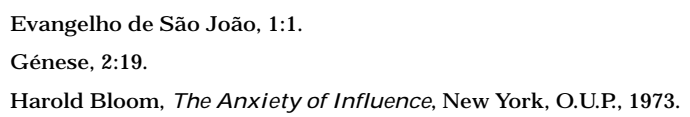


num combate que é o combate pela preeminência do Verbo, para B loom a crítica literária manifesta-se como análoga à poesia (visto que segundo ele cada poema seria também implicitamente a crítica literária de outro poema anterior). Por fim, segundo este enquadramento, o êxito de uma leitura crítica depende não da sua verdade mas da força retórica do próprio crítico. $\mathrm{E}$, no caso sobre o qual aqui nos debruçamos, como veremos, não só do crítico Machado em relação ao romancista E ça, mas ainda do romanci sta $M$ achado em relação ao seu irmão de armas português.

A proposta teórica de Bloom, apropriadamente, é ela própria uma revisão, ou resposta, ou reacção (filial) ao já conhecido conceito de talento artístico exposto por T.S. Eliot no seu famoso ensaio, "Tradition and the Individual Talent" ("A Tradição e o Talento Individual"8), e que B loom, edipianamente, não reconhece como seu percursor. Nesse texto, Eliot contende que um dos factores que definem a grandiosidade de um poeta é não a sua originalidade, a sua diferença em relação aos poetas que o antecederam, mas antes aqueles aspectos da sua obra que apontam para uma "consciência histórica" indicativa de que o poeta "escreve não apenas com a sua geração na medula, mas com o conhecimento de que toda a [tradição literária que o antecedeu] tem existência simultânea e constitui uma ordem presente."9 Segundo Eliot, esta percepção de uma história literária antepassada é, paradoxalmente, o que torna o poeta mais intrinsecamente consciente da sua contemporaneidade. ${ }^{10}$ É o que o transforma, por outras palavras, naquilo que Machado denominou "um homem do seu tempo e do seu país,"11 algo que este entendeu ser um dos padrões definidores da grandeza estética de um escritor. Ou que demonstra ter esse escritor (segundo a terminologia marxista de por exemplo G eorg L ukács, de cuja definição de grandeza estética Machado se aproxima curiosamente), um dedo no pulso da sua época, e a capacidade de se aperceber do momento presente como se este fosse já história passada. ${ }^{12}$ Assim, segundo E liot, que a teoria literária marxista tende a admirar, e cujo conceito M achado antecipou, o poeta para ser grande tem que desenvolver em si uma consciência da tradição passada capaz de iluminar a sua interpretação (profética) do presente.

R egressando à polémica $M$ achado/E ça, não nos esqueçamos de que, como o próprio Eça em muito citada corrrespondência debateu, o seu objectivo artístico, digamos que conseguido, estava tacitamente em perfeita harmonia com aquela intenção machadiana de escrever como "homem do seu tempo e do seu país":

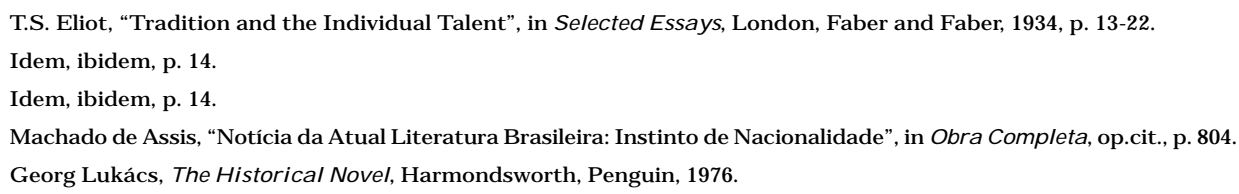


sendo esse objectivo, nas palavras do autor d'O Primo Basílio, precisamente o de fazer uma arte capaz de inserir-se num R ealismo que "deve ser perfeitamente do seu tempo, tomar a sua matéria na vida contemporânea."13 Torna-se então lícito perguntarmo-nos o que poderia ter havido nesse projecto, e na sua realização n'O Crime do Padre Amaro e n'O Primo Basílio, que tanto perturbou Machado, e ainda, quais foram os efeitos obscuros dessa perturbação.

Se nos debruçarmos sobre algumas das objecções detalhadas que Machado levanta na sua crítica ao Primo Basílio, e as examinarmos à luz da obra machadiana da segunda fase, inaugurada com aquelas Memórias Póstumas publicadas três anos depois d'O Primo Basílio, as conclusões são porventura interessantes. Uma das principais censuras dirigidas a $\mathrm{E}$ ça por M achado é a de ter aquele apresentado, em L uísa, a tal "queda que nenhuma razão moral explica," acima e famosamente citada. Se porém estabelecermos uma comparação entre Luísa e por exemplo as duas heroinas dos dois romances de $M$ achado que cronologicamente se seguiram a O Primo Basílio de Eça, verificamos a ocorrência de fenómenos exactamente análogos. Virgília, em Memórias Póstumas, tendo estado noiva (por conveniência) de Brás Cubas tal como Luísa esteve (por paixão) de Basílio, voluntariamente rejeita-o (tendo assim por essa razão ainda menos desculpa do que Luísa, separada de B asílio pela força das circunstâncias), e casa com L obo N eves que é melhor partido (assim como Luísa casa com J orge), mas mais tarde trai-lo com Brás (assim como Luísa trai J orge com Basílio). O próprio B rás Cubas dá voz àquela perplexidade que $\mathrm{M}$ achado, interrogando a questão de motivos, com maior verrina opôs a Luísa e ao seu criador:

“Mas, com a breca! quem me explicará a razão desta diferença? Um dia vimo-nos, tratámos o casamento, desfizemo-lo e separámo-nos, a frio, sem dor, porque não houvera paixão nenhuma; mordeu-me apenas algum despeito e nada mais. Correm anos, torno a vêla, damos três ou quatro giros de valsa, e eis-nos a amar um ao outro com delírio."14

E a resposta que ele mesmo dá à sua própria pergunta excede em depravação e imoralidade qualquer que Eça pudesse ter proporcionado: “a razão não podia ser outra senão o momento oportuno." 15 I sto é, Brás e Virgília pecam porque têm ocasião de pecar. Nada mais, nada menos, nem sequer a atenuante da memória de um antigo e ardente amor juvenil, que proventura até certo ponto desculparia Luísa. Também assim Sofia, em Quincas Borba, evita, por

\footnotetext{
E ça de Queirós, citado em J oão G aspar Simões, A Geração de 70, 2. ed., Lisboa, E ditorial Inquérito, s.d., p. 87-88. Machado de Assis, Memórias Póstumas de Brás Cubas, Porto, Lello \& Irmão, 1985, p. 118. Idem, ibidem.
} 
expediente de negócios, repelir o assédio amoroso de Rubião (visto ser este o sócio de negócios do marido), e não chega a atraiçoar o marido com Carlos M aria apenas porque este não Ihe dá oportunidade, embora a vaga possibilidade de um adultério indeterminado, seja com quem for, a atraia, em eco do desejo burguesinho de Luísa, de ter um amante, porque é chique tê-lo: ("Carlos M aria, Teófilo... O utros nomes relampejavam no céu daquela possibilidade,"16). $E$, mais flagrante ainda, no contexto de ligações extra-maritais que, nas palavras de Machado, "nenhuma razão moral ou paixão explica," seria o hipotético adultério de Capitu (que Machado insistiu em deixar como possibilidade no texto). F lagrante, visto que Capitu, tendo manipulado e trabalhado por casar com B ento, o trairia depois de casada, segundo esta hipótese, com um homem, Escobar, com quem anteriormente ao casamento com B ento, tinha convivido na intimidade durante os cinco anos da ausência daquele, e com quem teria tido nesse periodo ampla oportunidade de amar-se e casar-se. Nada explica o que distingue a ambiguidade moral de Capitu (que M achado sempre se recusou a desequivocar), da de Luísa, e porque razão Capitu (psicologicamente muito mais tenuamente esboçada do que L uisa), seria fascinante onde esta é condenada como lacunar.

Também assim, quando M achado acusa $\mathrm{E}$ ça de dar prioridade ao elemento acessório e pergunta que romance teria sido O Primo Basílio se as cartas de L uísa a Basílio não tivessem sido apanhadas pela chantagista J uliana, a resposta, curiosamente, é que esse romance teria sido As Memóri as Póstumas, no qual, precisamente, a ligação entre Virgília e B rás Cubas, não sendo nunca descoberta, definha e se desvanece, terminando com Virgília de regresso a seu marido e Brás Cubas, em eco da amoralidade de Basílio, confessando sentir "alguma coisa que não era dor nem prazer, uma coisa mista, alívio e saudade,"17 e com o famoso último capítulo "todo de negativas."18

Luísa peca como Virgília, sem razão e por fim sem paixão, e tal como Sofia "não tem remorsos, tem medo," 19 estes factos estabelecendo-a assim como parceira moral das duas heroinas machadianas. E se, como quis Machado, a única moral d'O Primo Basílio é que "a boa escolha dos fâmulos é uma condição de paz no adultério," 20 algo que Virgília e Sofia claramente aprenderam, o que o Dom Casmurro porventura nos ensina não será talvez mais do que o facto reco-

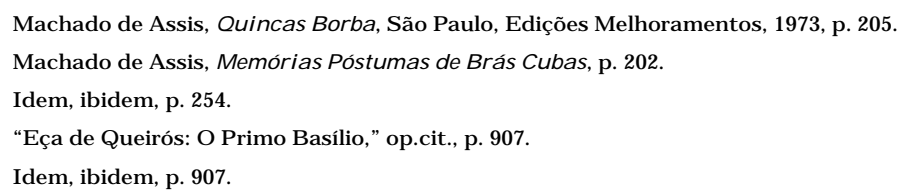


mendável de não chorar no funeral do amante, como sendo outra con dição dessa paz. $^{21}$

J oão Gaspar Simões ${ }^{22}$ atribuiu em grande parte à crítica de Machado de Assis contra O Primo Basílio, que encontrou eco noutra de Ramalho Ortigão, a crise intelectual que levou $\mathrm{E}$ ça a um eventual desencanto com a E scola Naturalista, e à procura de novas direcções que resultariam na apoteose d'Os Maias. Machado, e a sua implacável análise, teriam levado Eça a uma mudança de agulha que o transportou para a esfera da tragédia classicamente predestinada desse romance. Mas ironicamente, a trajectória seguida a partir desse momento pelo próprio Machado, e que resultaria, n’As Memórias Póstumas, numa reviravolta análoga para além de um delicodoce Romantismo brasileiro tardiamente moribundo, veio a aproximá-lo, paradoxalmente, daqueles defeitos do Naturalismo que E ça já tinha passado a corrigir em si. Assim, embora em Memórias Póstumas, com a sua filosofia paródica do Humanitismo, testemunhemos uma sátira feroz ao Realismo, ao Darwinismo, e ao culto positivista da ciência, aqui demolidos pela figura mítica e metafísica de Pandora, os dois principais pecados autorais por M achado atribuídos a $\mathrm{E}$ ça dão pela primeira vez sinal de si para não mais abandonarem a obra do grande romancista brasileiro. E este, Bloomianamente, passa assim inconscientemente a reproduzir em si aquilo que em Eça criticou. Temos primeiro o problemático (se aceitarmos que ele seja efectivamente problemático) delineamento de uma amoralidade sem explicação por parte dos protagonistas, já acima debatido com referência a Virgília, Sofia e Capitu, mas que mais implacavelmente se poderia aplicar a quase todos os personagens masculinos de Machado, mais particularmente Félix, Brás, Cristiano Palha, Carlos Maria, Bentinho, Pedro, Paulo e o Conselheiro Aires. Em segundo lugar, e a este primeiro fenómeno associada, está a abdicada responsabilidade moral relativamente à doutrina ética do romance, por parte do autor. Abdicação essa a qual nunca mais é restaurada nesta segunda fase da obra machadiana, arguivelmente caracterizada pelo abandono de posição autoral moral definida, em Memórias Póstumas e nos romances que se seguiram.

T.S. Eliot urgiu o poeta à apreensão dos seus antecessores, e Harold B loom apontou para a inevitabilidade com que essa apreensão assombra o artista cuja obra virá a definir-se através do imperativo de exorcisar os fantasmas desses mes-

${ }^{21}$ É talvez curioso observar aqui que o adultério de Virgília é denunciado ao marido por carta anónima, carta que este no entanto prefere não acreditar. E também Sofia quase é vítima de um mal-entendido revolvendo em redor de uma carta, mas neste caso um mal-entendido que a poderia incriminar tal como L uísa fica epistolarmente acusada. Machado assim recorre também ao tema de cartas denunciadoras, mas opta por torná-las periféricas, em vez de centrais ao enredo, uma decisão porventura ligada às suas objecções contra o romance queirosiano.

22 Eça de Quei rós: O Homem e o Arti sta, Lisboa, Edições Dois M undos, 1945, p. 392. 
mos antecessores, exorcismo nunca absolutamente conseguido. Se o que E ça fez em Portugal foi apontar para o vácuo ético de uma época e de um país cujo esvaziamento de plenitude moral, como Roberto Schwarz ${ }^{23}$ persuasivamente apontou, também preocupava Machado com urgência no Brasil, talvez a perturbação deste último, face à magistral exposição queirosiana de uma preocupação que em ambos escritores antecipou o baldio da angústia modernista, tenha sido a perturbação do artista forçado a reconhecer, num seu contemporâneo, um seu percursor. A perturbação, afinal, de ser intimamente forçado a admitir que no artista que ele publicamente censurou como o agente de uma corrente a que se opunha, ele encontrou afinal uma mente irmã, uma inquietante concordância: exactamente tal como se, nas palavras do próprio Machado, "aquela luva tivesse sido feita para aquela mão." 24 Ou encontrou enfim, Freudiana mas também muito americanamente, e brasileiramente, um tótem e não um tabu.

* Universidade de Cambridge, Inglaterra.

${ }^{1} \mathrm{~N}$ ão se pode propriamente chamar a este episódio uma polémica entre $\mathrm{M}$ achado e $\mathrm{E}$ ça, visto que a reacção profundamente generosa de $\mathrm{E}$ ça à resenha de M achado a'O Primo Basíli o, como se pode ver na carta abaixo citada, exclui desde o início qualquer hipótese de conflicto, pelo menos de carácter pessoal, embora abra a possibilidade de um debate acerca dos méritos da Escola Naturalista, mas debate esse no qual o próprio $\mathrm{E}$ ça, mais tarde ele mesmo desencantado com o Naturalismo, já não teria participado.

Newcastle-on-Tyne (Inglaterra), 29 de J unho de 1878.

Ex. ${ }^{\text {mo }}$ Sr. e prezado colega:

Uma correspondência do Rio de J aneiro para o "Actualidade" (jornal do Porto) revela ser o Sr. M achado de Assis, nome tão estimado entre nós, o autor do belo artigo sobre o "Primo B asílio" e o R ealismo publicado no "Cruzeiro" de 16 de Abril, assinado com o pseudónimo de "Eleuzar". Segundo essa correspondência há ainda sobre o romance mais dois folhetins de V. S. ${ }^{a}$ nos n. ${ }^{\circ}$ de 16 e 30 de Abril. Creio que outros escritores brasileiros me fizeram a honra de criticar o "Primo B asílio": - mas eu apenas conheço o folhetim de V. S.a, do dia 16, que foi transcrito em mais de um jornal português. O meu editor, Sr. Chardron, encarregou-se de coligir essas apreciações de que eu tenho uma curiosidade quasi ansiosa. E nquanto as não conheço, não posso naturalmente falar delas - mas não quis estar mais tempo sem agradecer a V. S. ${ }^{a}$ o seu excelente artigo do dia 16. A pesar de me ser em geral adverso, quasi revesso, e de ser inspirad o por uma hostilidade quasi partidá- 
ria à Escola R ealista - esse artigo todavia pela sua elevação e pelo talento com que está feito honra o meu livro, quasi Ihe aumenta a autoridade.

Quando conhecer os outros artigos de V. S. ${ }^{\text {a }}$ poderei permitir-me discutir as suas opiniões sobre este - não em minha defesa pessoal (eu nada valho), não em defesa dos graves defeitos dos meus romances, mas em defesa da Escola que eles representam e que eu considero como um elevado factor do progresso moral na sociedade moderna.

Quero também por esta carta rogar a V. S. ${ }^{\text {a }}$ queira em meu nome oferecer o meu reconhecimento aos seus colegas de literatura e de jornal pela honrosa aceitação que Ihes mereceu o "Primo B asílio". Um total acolhimento da parte de uma literatura tão original e tão progressiva como a do Brasil é para mim uma honra inestimável - e para o R ealismo, no fim de tudo, uma confirmação esplêndida de influência e de vitalidade.

Esperando ter em breve a oportunidade de conversar com V. S. ${ }^{a}$ - através do oceano sobre estas elevadas questões de Arte, rogo-Ihe queira aceitar a expressão do meu grande respeito pelo seu belo talento.

Addum au Consulat de Portugal. 